\title{
PELUANGA KERJA ALUMNI IAIN (Perspektif Sosiologis)
}

\author{
Jamal Syarif \\ Fakultas Tarbiyah IAIN Antasari Banjarmasin \\ E-mail:jamalsyarif@yahoo.com
}

\begin{abstract}
Abstrak: Lembaga pendidikan/sekolah dipandang selain mengajarkan pengetahuan dan keterampilan juga berperan secara efektif menanamkan nilai-nilai modern yang diperlukan sebagai prasyarat bagi tiap bangsa yang hendak memasuki era industrialisasi. Sekolah juga dipandang sebagai salah satu alat sosialisasi yang penting (selain keluarga dan masyarakat) yang senantiasa direkayasa golongan yang berkuasa untuk melestarikan struktur sosial yang sudah ada. Selain itu sekolah juga dipandang sebagai suatu pasar budaya (culture market), di mana faktor-faktor sosial secara serentak berusaha untuk mencapai tujuan-tujuan tertentu atau mencari sesuatu yang dipertukarkan, seperti ijazah, prestise, kontrol atas kelas sosial tertentu, dan kualifikasi sosial lainnya.

Abstract: Educational institutions/schools considered in addition to teaching the knowledge and skills also contribute effectively instill modern values is required as a prerequisite for any nation that was about to enter the era of industrialization. Schools are also considered as one of the important socialization tool (in addition to the family and community) that the ruling class always engineered to preserve the existing social structure. Schools were seen as a market culture (culture market), in which social factors are simultaneously trying to achieve certain goals or exchanged for something, such as a diploma, prestige, control over certain social class, and other social qualifications .
\end{abstract}

Kata Kunci: Lapangan pekerjaan, fakultas, alumni, dan status sosial 


\section{PENDAHULUAN}

Ada banyak orang yang bekerja tetapi tidak sesuai dengan disiplin keilmuan semasa dia kuliah. Secara riil ada banyak alumni IAIN yang bekerja, namun tidak sedikit pula mereka bekerja hanya sekedar untuk tidak dikatakan sebagai pengangguran, dalam artian menerima apapun pekerjaan yang bisa dia lakukan tanpa didasari oleh keahlian kesarjanaannya. Kenyataan ini tidak bisa dielakkan karena cepatnya pertambahan alumni perguruan tinggi tidak sebanding dengan tersedianya kesempatan kerja untuk menampung alumni tersebut.

Melihat kenyataan tersebut, siapapun yang terlibat dalam dunia pendidikan atau bahkan yang tidak terlibat sekalipun merasakan adanya ketidakpastian dengan sistem pendidikan saat ini. Tidak ada seorang pun yang bisa memastikan bahwa seorang sarjana syari'ah akan bekerja di Pengadilan Agama dan KUA, begitu juga sama tidak pastinya sarjana tarbiyah akan bekerja sebagai guru; atau sarjana dakwah sebagai penyiar atau da'i. Dari situasi ini muncul pertanyaan: apakah seorang sarjana dari disiplin ilmu tertentu bekerja sesuai dengan disiplin ilmunya? Idealnya, jawaban dari pertanyaan tersebut menghendaki jawaban yang positif, namun realitanya bisa saja seorang sarjana dari disiplin ilmu tertentu bekerja di lapangan pekerjaan yang tidak sesuai atau bahkan berlainan dengan disiplin ilmu pada saat dia mengenyam pendidikan di bangku kuliah.

Beranjak dari asumsi-asumsi di atas, tulisan ini berusaha menjawab pertanyaan apakah seseorang akan bekerja sesuai dengan disiplin ilmu yang dia tempuh selama sekolah/kuliah? Analisis terhadap persoalan ini akan dilakukan dengan menggunakan ulasan teori konflik terhadap dunia pendidikan. Untuk menjawab pertanyaan tersebut, terlebih dahulu penulis kemukakan pandangan sosiologi terhadap pendidikan, khususnya lembaga pendidikan. 


\section{LEMBAGA PENDIDIKAN DALAM PANDANGAN SOSIOLOGIS}

Lembaga pendidikan yang penulis maksudkan di sini adalah lembaga pendidikan formal, yakni lembaga pendidikan yang sudah diatur secara sistematis, terencana, berjenjang, memiliki kurikulum tertentu dan batas waktu penyelenggaraannya, atau dengan kata lain pendidikan persekolahan.

Bagi seorang anak, dan bahkan bagi orang tuanya, bersekolah mungkin akan membuka kesempatan untuk mengembangkan diri dan memudahkan perpindahan memasuki suatu status elit. Anak yang sebelumnya berada dalam status sosial yang rendah, bisa naik secara langsung atau tidak langsung ke status sosial yang lebih tinggi hanya dengan memasuki sekolah.

Tak begitu jelas apa saja alasan orang tua mengizinkan atau memasukkan anaknya ke sekolah. Mungkin alasannya bermacammacam dan berbeda-beda secara individual, namun diduga ada kesamaan menurut pandangan masing-masing apa yang diharapkan dari sekolah:

- Sekolah dianggap dapat mempersiapkan anak untuk suatu pekerjaan. Anak yang telah menamatkan sekolah diharapkan sanggup melakukan pekerjaan sebagai mata pencaharian atau setidaknya mempunyai dasar untuk mencari nafkah. Makin tinggi pendidikan, makin besar harapannya untuk memperoleh pekerjaan yang baik. Ijazah masih tetap dijadikan prasyarat penting untuk suatu jabatan, walaupun ijazah itu sendiri belum menjamin kesiapan seseorang untuk melakukan pekerjaan tertentu. Akan tetapi dengan ijazah yang tinggi seseorang dapat memahami dan menguasai pekerjaan kepemimpinan atau tugas lain yang dipercayakan kepadanya. Memiliki ijazah perguruan tinggi merupakan salah satu bukti akan kesanggupan intelektualnya untuk menyelesaikan studinya yang tidak mungkin dicapai oleh orang yang rendah kemampuannya. 
- Sekolah membuka kesempatan memperbaiki nasib. Sekolah sering dianggap sebagai jalan bagi mobilitas sosial. Melalui pendidikan orang dari golongan rendah dapat meningkatkan ke golongan yang lebih tinggi. Orang tua mengharapkan agar anak-anaknya mempunyai nasib yang lebih baik dan karena itu berusaha untuk menyekolahkan anaknya jika mungkin memperoleh gelar yang setinggi-tingginya walaupun sering dengan pengorbanan yang besar mengenai pembiayaannya. Tidak jarang anak seorang guru SD, penyapu halaman sekolah, pedagang kecil atau sopir menyekolahkan anaknya sampai perguruan tinggi. Pada zaman sekarang sekolah menengah apalagi sekolah dasar tidak berarti lagi bagi mobilitas sosial atau untuk memperbaiki status sosial seseorang. Akan tetapi gelar akademis sangat membantu untuk menduduki tempat yang terhormat dalam dunia pekerjaan. Mereka yang telah menduduki tempat yang tinggi memandang pendidikan sebagai syarat mutlak untuk mempertahankan status sosialnya.

- Sekolah membentuk manusia yang sosial. Pendidikan diharapkan membentuk manusia sosial, yang dapat bergaul dengan sesama manusia sekalipun berbeda agama, suku, bangsa, pendirian, dan sebagainya. Ia juga harus dapat menyesuaikan diri dalam situasi sosial yang berbeda-beda.

- Sekolah merupakan alat mentransformasi kebudayaan. Sekolah terutama perguruan tinggi diharapkan menambah pengetahuan dengan mengadakan penemuan-penemuan baru yang dapat membawa perubahan dalam masyarakat. Perkembangan ilmu pengetahuan dan teknologi telah membawa perubahan yang besar di dunia ini. ${ }^{1}$

Terdapat berbagai perspektif sosiologis dalam memandang pendidikan terutama mengenai fungsi sekolah sebagai lembaga pendidikan formal bagi masyarakat maupun bagi

${ }^{1}$ S. Nasution, Sosiologi Pendidikan, (Jakarta: Bumi Aksara, 1995), h. 14 
penyelengganya. Berikut ini penulis kemukakan perspektif teori fungsionalis, teori konflik dan teori pertukaran.

\section{Perspektif Teori Fungsionalisme}

Ditinjau dari perspektif fungsionalisme, sekolah sebagai suatu subsistem di masyarakat memiliki fungsi yang penting dalam sistem sosial. Sebagai suatu subsistem yang penting dalam masyarakat, lembaga ini akan terus tetap bertahan. Sekolah dipandang selain mengajarkan pengetahuan dan keterampilan juga berperan secara efektif menanamkan nilai-nilai modern yang diperlukan sebagai prasayarat bagi tiap bangsa yang hendak memasuki era industrialisasi.

Menurut aliran ini, pada dasarnya keterbelakangan suatu masyarakat bukan dikarenakan masalah struktur (misalnya adanya perangkat aturan atau undang-undang yang membatasi akses terhadap sumber-sumber ekonomi dan kekuasaan), tetapi disebabkan karena adanya cultural deficiency atau kekurangan unsur-unsur nilai modern yang diperlukan suatu masyarakat untuk maju dan memasuki era industrialisasi, seperti kewiraswastaan, keberanian mengambil resiko, kreativitas, motivasi berprestasi, dan sikap-sikap lainnya.

Beranjak dari asumsi itu, sekolah dianggap sebagai agen paling efektif menanamkan nilai-nilai itu pada individu. Melalui proses sosialisasi di sekolah tersebut, pembangunan industri akan dapat diperlancar. Lebih lanjut aliran ini menganggap bahwa sikap modern bukan diperoleh melalui pemberian materi pelajaran, tetapi lebih penting adalah proses interaksi sosial yang berlangsung di sekolah (terutama di kelas). Bahkan Emile Durkheim mendefinisikan pendidikan sebagai sarana untuk mensosialisasikan anak didik. ${ }^{2}$

${ }^{2}$ Emile Durkheim, Education and Sociology, (New York: The Free Press, 1956), h. 32. Lihat juga Paulus Wirutomo, "Sekolah, Mampukah Membebaskan 
Sekolah menurut pandangan fungsionalism dapat berfungsi sebagai 1) sarana pentransmisian budaya. Sekolah tidak hanya pentransferan pengetahuan, keterampilan dan nilai-nilai tertentu saja, tetapi juga merupakan sarana transmisi budaya antar orangorang yang berada di sekolah tersebut. Satu sama lain bisa masuk dan keluar dari budaya-budaya yang ada. Sekolah juga merupakan pembentuk kebudayaan sesuai dengan kebudayaan apa ingin dikehendaki. 2) sarana untuk integrasi sosial. Dalam masyarakat modern yang terdiri banyak orang yang berbeda, baik suku, ras agama atau bahkan kebudayaan. Sekolah dapat membantu ke arah pengintegrasian kelompok-kelompok tersebut. Pendidikan dapat membuat kaum minoritas masuk menyatu dan berbaur dalam kehidupan masyarakat mayoritas. 3) sarana untuk pengembangan diri. Sekolah tempat untuk mengajarkan keterampilan. Kebanyakan dari berbagai pihak mengharapkan ada kegunaaan praktis bagi siswa dikehidupan mereka kelak. 4) sarana penyaringan dan pemilihan. Berbagai sekolah ditawarkan sesuai dengan macam dan jenis pekerjaan yang dikehendaki. Seseorang bisa memilih sekolah yang sesuai dengan pekerjaan yang diharapkannya setelah lulus. 5) sarana untuk inovasi. Pendidikan tidak melulu mengajarkan tentang pengetahuan saja, dia juga menawarkan berbagai cara untuk mengembangkan keterampilan dan pengetahuan dan penemuan baru yang berguna bagi masyarakat. 6) fungsi laten. Sekolah tidak hanya mempunyai fungsi manifes atau fungsi yang diketahui sebagaimana nomor satu sampai lima, tetapi juga memiliki fungsi laten atau fungsi yang tidak diketahui. Fungsi laten tersebut misalnya kedisiplinan, kepatuhan atau ketaatan kepada orang atau sekelompok orang yang memegang kekuasaan. Fungsi ini berusaha menanamkan

Manusia?" dalam Tonny D. Widiastono (ed.), Pendidikan Manusia Indonesia, (Jakarta: Penerbit Buku Kompas, 2004), h. 253-55 
nilai-nilai tertentu kepada anak didik untuk kepentingan pihak tertentu. $^{3}$

\section{Perspektif Teori Konflik}

Menurut aliran konflik Marxian (yang diwakili oleh Bowles dan Gintis), materi adalah faktor satu-satunya yang menentukan pola perilaku manusia, struktur sosial adalah produk dari hubungan sosial dalam rangka menghasilkan materi. Karena itu sejarah manusia senantiasa ditandai konflik antara golongan yang ingin merombak dan mempertahankan hubungan sosial yang sudah mapan. Aliran ini melihat sekolah sebagai salah satu alat sosialisasi yang penting (selain keluarga dan masyarakat) yang senantiasa direkayasa golongan yang berkuasa untuk melestarikan struktur sosial yang sudah ada. Sekolah bukan saja berperan memberi pengetahuan dan melatih keterampilan yang dibutuhkan dalam dunia kerja, tetapi berperan juga dalam mensosialisasikan nilai-nilai yang dituntut oleh hirarki birokrasi.

Dalam keluarga-keluarga di Indonesia, baik dari kelas bawah sampai kelas atas, semua orang tua menanamkan pada anak bahwa sekolah adalah lembaga yang amat mereka perlukan agar dapat tetap survive di masyarakat dan dapat memberikan sertifikasi/ijazah pada semua orang untuk dapat memasuki dunia kerja yang mereka inginkan. Maka setiap tahun orang tua harus bersusah payah mencari dana untuk memasukkan anaknya ke sekolah.

Di sekolah, anak diajarkan untuk bersikap, berpikir, dan bertindak sesuai nilai dan norma yang dibutuhkan dunia kerja yang kapitalis seperti kepatuhan, sopan santun, kerja keras dan disiplin. Melalui sekolah, para siswa disiapkan untuk mau dan mampu menerima budaya dunia kerja. Dunia kerja tinggal menerima para lulusan yang siap pakai, artinya siap dipekerjakan

\footnotetext{
${ }^{3}$ Ian Robertson, Sociology, ( New York: Worth Publishers. Inc, Third Edition, 1988), h. 378-80
} 
sebagai alat produksi yang efektif serta memiliki struktur kepribadian yang patuh dan taat terhadap budaya kapitalis. ${ }^{4}$

Lain lagi dengan aliran konflik Weberian. Bila kelompok Marxian percaya bahwa sumber yang paling mendasar dan paling diperebutkan adalah materi, maka aliran konflik Weberian yakin bahwa selain materi ada sumber lain yang diperebutkan yaitu kekuasaan (power) serta kehormatan (status atau privilege) yang ada dalam ranah budaya karena terkait dengan sistem nilai.

Aliran Weberian pada dasarnya memandang sekolah sebagai lembaga yang direkayasa untuk menyaring secara budaya para anggota kelas bawah yang akan diterima dalam kelas yang lebih tinggi. Karena itu peran sekolah sebagai tempat untuk memperoleh modal budaya (cultural capital) bagi para siswa. Semakin tinggi tingkat pendidikan seseorang, maka semakin banyak cultural capital yang mereka dapatkan dan dengan cultural capital ini mereka kian mudah diterma dalam budaya kelas sosial yang lebih tinggi. Sementara golongan miskin yang tidak mampu memanfaatkan sekolah secara optimal akan semakin sulit menembus batas-batas kelas sosialnya. Kesulitan orang miskin secara finansial untuk membiayai sekolah ke jenjang pendidikan lebih tinggi merupakan proses penyaringan ekonomi -- hal ini lebih banyak dibahas oleh aliran konflik Marxian -- sementara aliran konflik Weberian lebih menyoroti hambatan-hambatan yang dihadapi orang miskin untuk memperoleh dan menyesuaikan diri dengan budaya kelas menengah di sekolah. Hal ini merupakan suatu penyaringan budaya untuk membentengi masuknya golongan kelas bawah ke kelas menengah atau atas sehingga struktur sosial yang ada dapat dipertahankan. ${ }^{5}$

\footnotetext{
${ }^{4}$ Tonny D. Widiastono (ed.), Pendidikan...., h. 256

${ }^{5}$ Ibid., h. 258. Di Amerika, anak-anak memasuki sekolah yang berbeda sesuai dengan perbedaan kelas mereka. Anak-anak kelas atas memasuki sekolah swasta yang elit, sementara anak-anak dari kelas menengah memasuki
} 


\section{Perspektif Teori Pertukaran}

Teori pertukaran melihat bahwa dalam lembaga sekolah ada suatu hal yang dipertukarkan sehingga terjadilah suatu interaksi di dalamnya. Baik guru, siswa orang tua, penguasa maupun mayarakat secara umum berusaha mencari hal yang bisa menguntungkan bagi diri mereka masing-masing.

Berdasarkan teori ini sekolah dipandang sebagai suatu pasar budaya (culture market), di mana faktor-faktor sosial secara serentak berusaha untuk mencapai tujuan-tujuan tertentu atau mencari sesuatu yang dipertukarkan. Di dalam pasar itu, kelompok-kelompok yang berbeda mungkin mengikuti pola-pola pembelian yang serupa namun dengan pertimbanganpertimbangan yang berbeda. Pemerintah pusat umpamanya, melihat sekolah sebagai sarana untuk mempertahankan kontrolnya atas kelas-kelas tertentu, sementara dalam waktu yang bersamaan anggota kelas memandang sekolah sebagai sarana untuk meningkatkan status mereka. Pasar menyesuaikan diri kepada ragam permintaan melalui "mata uang" yang berupa ijazah dan kualifikasi formal lainnya. Kecenderungan setiap masyarakat adalah permintaan akan sertifikat-sertifikat formal yang tiap hari kian tinggi sebagai lisensi untuk memasuki dunia pekerjaan tertentu. Kondisi ini telah memaksa terjadinya inflasi ijasah sebagai kecenderungan umum dari permintaan setiap masyarakat. ${ }^{6}$

Selain ada hal yang bisa dipertukarkan, sebagaimana penjelasan di atas, salah satu unsur pendidikan yang paling penting adalah mekanisme hukuman dan ganjaran (reward and punishment). Sistem pemberian nilai dalam ujian misalnya merupakan mekanisme memberi ganjaran pada murid yang rajin atau berprestasi dan memberi hukuman pada murid yang tidak

sekolah negeri pinggiran kota, dan anak-anak dari kelas bawah memasuki sekolah negeri dalam kota. Ian Robertson, Sociology..., h. 381

6 Philip Robinson, Beberapa Perspektif Sosiologi Pendidikan, (Jakarta: Rajawali, 1986), h. 312 
berprestasi. Mekanisme ini bila dilakukan dengan baik dan konsekuen akan amat penting dan efektif untuk membentuk sikap siswa dan pola perilaku siswa secara keseluruhan (misalnya sikap rajin, disiplin, kerja keras, berprestasi, dan sebagainya). Akan tetapi dalam sistem persekolahan ada gejala kekaburan konsep disertai melemahnya kewibawaan sekolah dalam memberi hukuman dan ganjaran ini. Di satu pihak sekolah tidak berani atau tidak tegas untuk menentukan apakah murid memenuhi kualifikasi yang sudah ditetapkan atau tidak (misalnya banyak hasil ujian di semua sekolah yang hampir lulus 100\%), di lain pihak sekolah kurang memberi penghargaan pada murid yang rajin dan berprestasi dengan ganjaran sosial yang membanggakan, sehingga sistem persekolahan tidak memberi kriteria pemberian reward and punishment yang jelas. Akibatnya menghasilkan sikap dan pola perilaku siswa yang tidak disiplin ${ }^{7}$ dan lebih jauh lagi bisa menghasilkan disorientasi nilai. Penentuan prestasi murid kebanyakan hanya didasari aspek pengetahuan bukan prestasi di bidang lainnya (olah raga, kesenian, keterampilan sosial, budi pekerti, dan sebagainya) sehingga para siswa menganggap, prestasi di bidang lainnya tidak ada artinya. Itu sebabnya para siswa kehilangan kreativitas dan motivasi berprestasi di berbagai bidang kehidupan. Sikap dan pola perilaku siswa juga dapat dibentuk dengan menata aturan, tata tertib serta tradisi-tradisi yang baik di sekolah. Mekanisme sistem reward and punishment ini pulalah yang menjadi fokus perhatian teori pertukaran.

\section{LEMBAGA PENDIDIKAN DAN DUNIA KERJA}

Berdasarkan beberapa perspektif sosiologis terhadap lembaga pendidikan di atas, berikut penulis memfokuskan pandangan teori konflik terhadap dunia kerja.

\footnotetext{
${ }^{7}$ Emile Durkheim, Education..., h. 98
} 
Sekolah merupakan sebuah miniatur sistem sosial. Di sana terdapat status dan peran, nilai, dan tradisi serta ritual dan ceremonial. Setiap sekolah atau kelas merupakan sebuah unit interaksi sosial. ${ }^{8}$ Sebagai suatu sistem sosial atau sistem kemasyarakatan yang kecil, sekolah merupakan cermin dari masyarakat secara makro. Apa yang terdapat dan terjadi di masyarakat, pada dasarnya terwujud juga dalam sekolah. Oleh karena itu, semakin baik seseorang memahami masyarakat, semakin baik pula dia bisa mempertanggungjawabkan dan mengaplikasikan pemahamannya tersebut ke dalam sebuah masyarakat kecil yakni sekolah. ${ }^{9}$

Di sekolah terdapat aturan-aturan yang mengikat para anggotanya, baik anak didik maupun guru. Ada norma-norma dalam pergaulan yang harus dipatuhi, terdapat interaksi antara sesama baik secara individual maupun kelompok, terdapat konflik-konflik interes baik nampak maupun tersembunyi. Sangsi-sangsi akan dijatuhkan kepada siapa saja yang melangggar tatanan yang ada.

Dalam proses interaksi tersebut, termasuk di dalamnya proses pembentukan kepribadian, sikap, rasa, dan juga intelektualitas, sekolah sebagai sebuah masyarakat kecil sangat penting artinya. Sikap dan pola perilaku siswa dapat dibentuk dengan menata aturan, tata tertib serta tradisi-tradisi yang baik di sekolah. Karena siswa ada di dalam lingkungan sosial seperti itu selama bertahun-tahun, maka akan terbentuklah suatu sikap dan pola perilaku tertentu kepadanya. Misalnya aturan di sekolah yang ketat dan tegas akan menghasilkan murid yang disiplin. Di samping itu, adanya kegiatan-kegiatan ekstra-kurikuler di sekolah merupakan sarana efektif dalam rangka menanamkan sikap, pola pikir, dan pola berperilaku yang ingin terapkan pada

\footnotetext{
${ }^{8}$ Ian Robertson , Sociology ...,., h. 381

${ }^{9}$ Emile Durkheim, Education..., h. 131
} 
anak didik. Hal ini merupakan hasil dari proses sosialisasi yang terjadi di sekolah. ${ }^{10}$

Dalam masyarakat yang hidup di era industrialisasi sekarang ini, sosialisasi yang terjadi di sekolah lebih banyak mengarahkan siswa-siswanya untuk memasuki dunia kerja. Sehingga dalam segala tindak-tanduk, sikap, perilaku, pandangan, bahkan pengajarannya selalu diorientasikan kepada dunia kerja. Implikasinya banyak siswa dan orang tuanya mempertanyakan apa yang akan dia kerjakan setelah lulus dari sekolah. Pandangan ini membuat fakultas/jurusan yang dianggap laku di dunia kerja menjadi pilihan favorit bagi siswa dan orang tuanya.

Berbeda sekali dengan orientasi sebelum era industrialisasi. Dahulu siswa pergi ke sekolah untuk belajar bidang tertentu yang sesuai dengan keinginan mereka atau yang menarik bagi diri mereka. Tapi sekarang banyak siswa pergi ke sekolah untuk belajar bidang studi yang dapat menghasilkan pekerjaan atau yang memiliki prospek kerja yang lebih luas. Di Amerika misalnya, tahun 1985 sebanyak 70\% orang memilih jurusan di perguruan tinggi yang dapat menghasilkan uang lebih banyak. Bisa dibandingkan pada tahun 1970an hanya sekitar 50\% saja yang memilih ke arah itu. Para siswa cenderung memilih jurusan yang mereka pikir akan mudah bagi mereka diterima di dunia kerja. ${ }^{11}$ Kecenderungan ini pun rasanya tidak jauh beda dengan yang terjadi di Indonesia.

Namun demikian, jika kecenderungan pilihan tersebut disebabkan oleh keinginan untuk bisa dengan mudah masuk

${ }^{10}$ Penanaman kepribadian, sikap, rasa, dan juga intelektualitas di sekolah merupakan salah satu contoh konflik pendidikan yang implisit. Sementara adanya kegiatan-kegiatan ekstra kureluler merupakan contoh dari adanya konflik pendidikan yang eksplisit. Lihat Kathy Bickmore "Conflict Resolution Education: Multiple Options for Contributing to Just and Democratic Peace" dalam William J. Pammer, Jr \& Jerri Killian (ed.), Handbook of Conflik Management, (New York: Marcel Dekker Inc., 2003), h. 7

${ }^{11}$ Ibid., h. 393 
dunia kerja, maka muncul pertanyaan: apakah mereka yakin bahwa setelah mereka lulus, mereka akan bisa bekerja sesuai dengan jurusannya? Untuk menjawab pertanyaan tersebut, penulis menampilkan data empiris tentang ketidak-sesuaian antara fakultas yang dipilih dengan lapangan kerja yang diambil oleh alumni IAIN berikut ini:

Penyebaran Bidang Pekerjaan Alumni S1 Adab

(244 Responden),

S1 Dakwah (275 Responden), S1 Syari'ah (151 Responden),

S1 Tarbiyah

(439 Responden), dan S1 Ushuluddin (120 Responden) $)^{12}$

\begin{tabular}{|c|c|c|c|c|c|c|c|c|c|c|}
\hline \multirow{2}{*}{$\begin{array}{c}\text { Bidang } \\
\text { Pekerjaan }\end{array}$} & \multicolumn{2}{|c|}{ Adab } & \multicolumn{2}{|c|}{ Dakwah } & \multicolumn{2}{|c|}{ Syariah } & \multicolumn{2}{|c|}{ Tarbiyah } & \multicolumn{2}{|c|}{ Ushuluddin } \\
\hline & $\mathrm{F}$ & $\%$ & $\mathbf{F}$ & $\%$ & $\mathbf{F}$ & $\%$ & $\mathbf{F}$ & $\%$ & $\mathbf{F}$ & $\%$ \\
\hline Pendidikan & 113 & 82.5 & 182 & 66.2 & 91 & 60.3 & 392 & 89.3 & 89 & 74.2 \\
\hline Keagamaan & 52 & 38.0 & 149 & 54.2 & 77 & 51.0 & 188 & 42.8 & 68 & 56.7 \\
\hline Perdagangan & 15 & 10.9 & 35 & 12.7 & 17 & 11.3 & 40 & 9.1 & 15 & 12.5 \\
\hline Informasi & 8 & 5.1 & 15 & 5.5 & 5 & 3.3 & 14 & 3.2 & 10 & 8.3 \\
\hline Administrasi & 14 & 10.2 & 30 & 10.9 & 14 & 9.3 & 29 & 6.6 & 8 & 6.7 \\
\hline Lingkungan & 3 & 2.2 & 10 & 3.6 & 7 & 4.6 & 5 & 1.1 & 7 & 5.8 \\
\hline Kesehatan & 2 & 1.5 & 8 & 2.9 & 5 & 3.3 & 7 & 1.6 & 7 & 5.8 \\
\hline Pertanian & 7 & 5.1 & 9 & 3.3 & 6 & 4.0 & 10 & 2.3 & 5 & 4.2 \\
\hline $\begin{array}{l}\text { Kebudayaan/ } \\
\text { kesenian }\end{array}$ & 13 & 9.5 & 13 & 9.5 & 4 & 2.6 & 11 & 2.5 & 5 & 4.2 \\
\hline Keuangan & 2 & 1.5 & 8 & 2.9 & 6 & 4.0 & 8 & 1.8 & 6 & 5.0 \\
\hline Hukum & 3 & 2.2 & 10 & 3.6 & 34 & 22.5 & 3 & 0.7 & 3 & 2.5 \\
\hline Konstruksi & 1 & 0.7 & 3 & 1.1 & 1 & 0.7 & 4 & 0.9 & 2 & 1.7 \\
\hline Otomotif & 1 & 0.7 & 3 & 1.1 & 2 & 1.3 & 2 & 0.5 & 1 & 0.8 \\
\hline Komputer/ & 2 & 1.5 & 1 & 0.4 & 5 & 3.3 & 6 & 1.4 & 1 & 0.8 \\
\hline
\end{tabular}

${ }^{12}$ Data ini penulis ambil dari penelitian Mastuhu tentang dunia kerja alumni IAIN. Penelitiannya menjangkau tiga IAIN yakni IAIN Jakarta (Sekarang UIN), IAIN Yogyakarta (sekarang UIN) dan IAIN Surabaya., meliputi alumni S1 Fakultas Tarbiyah, Syari'ah, Dakwah, Adab, dan Ushuluddin. Lihat Mastuhu, Memberdayakan Sistem Pendidikan Islam, (Jakarta: Logos Wacana Ilmu, 1999), h. 186-92 


\begin{tabular}{lcccccccccc}
\hline elektronika & & & & & & & & & & \\
\hline Perbankan & 1 & 0.7 & 1 & 0.4 & 1 & 0.7 & 3 & 0.7 & 1 & 0.8 \\
\hline Lainnya & 7 & 5.1 & 23 & 8.4 & 13 & 8.6 & 15 & 3.4 & 9 & 7.5 \\
\hline
\end{tabular}

Dari data tersebut terlihat bahwa semua alumni IAIN sebagian besar masuk dalam lapangan pekerjaan bidang pendidikan. Kecuali Alumni Fakultas Tarbiyah, fakultas lainnya menggambarkan ketidak-sesuaian antara fakultas yang ditempuh dengan pekerjaan yang diambil setelah lulus kuliah. Alumni Fakultas Tarbiyah pun tidak tertampung sepenuhnya dalam lapangan pekerjaan yang sesuai dengan disiplin ilmunya.

Adanya kenyataan bahwa alumni fakultas selain tarbiyah bisa memasuki lapangan pekerjaan bidang pendidikan, bisa dimaklumi karena IAIN mengajarkan disiplin Islamic studies/dirasah Islamiyah untuk semua fakultas yang ada. Hal ini bisa menjadi modal pengetahuan bagi para alumni tersebut dan memberi kesempatan yang luas untuk bisa memasuki lapangan pekerjaan bidang pendidikan/mengajar.

Walaupun demikian, untuk bisa mengajar tidak hanya dituntut kompetensi penguasaan materi pelajaran, yang lebih penting adalah kompetensi metodologi mengajar. Walaupun seseorang memiliki penguasaan ilmu yang luas, belum tentu dia bisa mengajarkan ilmu tersebut kepada orang lain (siswa). Kemampuan metodologis mengajar ini yang tidak dimiliki oleh para alumni selain tarbiyah. Keadaan demikian menyebabkan adanya ketidak-profesionalan pekerjaan yang diambil para alumni IAIN tersebut. Di samping itu, banyaknya para alumni selain tarbiyah memasuki bidang pekerjaan pendidikan membawa implikasi kepada besarnya minat orang tua atau masyarakat pada umumnya untuk memasukkan anaknya ke Fakultas Tarbiyah. Melihat kenyataan tersebut, masyakat melihat Fakultas Tarbiyah memberikan prospek pekerjaan yang relatif banyak dan mudah dijangkau. 
Jika melihat data di atas, alumni IAIN bekerja pada hampir semua bidang kehidupan yang tampak jauh dan tidak ada relevansinya dengan bidang yang dipelajari di IAIN. Data ini merupakan salah satu bukti empiris bahwa seseorang tidak mesti bekerja sesuai dengan fakultas/jurusan yang ditempuhnya sewaktu mereka kuliah. Keadaan seperti ini bisa menimbulkan interest conflicts pada diri alumni itu sendiri. ${ }^{13}$ Karena merasa pekerjaannya tidak sesuai dengan keinginannya sebelumnya, maka akan menimbulkan konflik keinginan pada dirinya sendiri. Implikasinya muncul dalam bentuk ketidak-profesionalan terhadap pekerjaan, kurangnya tanggung jawab terhadap orang lain sebagai pemakai jasa dari pekerjaan tersebut, dan lebih parah lagi kurangnya semangat untuk lebih mengembangkan kualitas diri.

Kenyataan tersebut juga menunjukkan bahwa adanya kesempatan yang luas bagi alumni IAIN untuk memasuki berbagai bidang kehidupan dengan modal pengetahuan Islamic studiesnya. Namun demikian, bisa juga dikatakan bahwa keadaan tersebut terjadi karena adanya kesempitan lapangan pekerjaan yang sesuai dengan disiplin ilmu/fakultas/jurusan yang ada di IAIN. Dengan demikian bisa dikatakan bahwa para alumni IAIN tersebar di berbagai lapangan pekerjaan karena adanya kesempatan dan kesempitan lapangan pekerjaan. Satu sisi, kesempatan yang luas karena para alumni dibekali ilmu pengetahuan yang relatif general sehingga bisa memasuki berbagai lapangan pekerjaan. Di sisi lain dikatakan adanya kesempitan, karena sempitnya kesempatan para alumni untuk

${ }^{13}$ Konflik keinginan ini merupakan salah satu bagian dari konflik interpersonal yang terbagi tiga, yakni: 1) konflik hubungan, berkaitan dengan pandangan seseorang terhadap perlakuan orang lain; 2) konflik identitas, berhubungan dengan masalah suku, agama, ras, dan jenis kelamin; dan 3) konflik keinginan, berhubungan dengan ketidaksesuaian terhadap keinginan pribadi. Lihat Mary Wenning "Experiential Learning: Culture and Conflict" dalam William J. Pammer, Jr \& Jerri Killian (ed.), Handbook..., h. 87 
bekerja sesuai dengan disiplin ilmu/fakultas/jurusan yang ditempuhnya.

Jika kenyataan ini menggambarkan dunia pendidikan dan lapangan pekerjaan secara umum di Indonesia, maka masih bisakah seseorang dikatakan masuk ke sekolah/perguruan tinggi untuk meningkatkan status sosialnya? atau untuk membuat hidup lebih baik? (Sebagaimana yang dipandang para sosiolog). Mungkin untuk sekarang, jawabannya memang seperti itu. Seseorang atau orang tua yang memiliki anak yang sudah sarjana dipandang memiliki status sosial yang lebih tinggi dibanding dengan seseorang atau orang tua yang memiliki anak yang tidak kuliah.

\section{PENUTUP}

Dari uraian di atas, dapat disimpulkan bahwa:

- Sebagai suatu subsistem yang penting dalam masyarakat, sekolah dipandang selain mengajarkan pengetahuan dan keterampilan juga berperan secara efektif menanamkan nilainilai modern yang diperlukan sebagai prasyarat bagi tiap bangsa yang hendak memasuki era industrialisasi. Di samping itu sekolah dipandang sebagai salah satu alat sosialisasi yang penting (selain keluarga dan masyarakat) yang senantiasa direkayasa golongan yang berkuasa untuk melestarikan struktur sosial yang sudah ada. Selain itu sekolah juga dipandang sebagai suatu pasar budaya (culture market), di mana faktor-faktor sosial secara serentak berusaha untuk mencapai tujuan-tujuan tertentu atau mencari sesuatu yang dipertukarkan, seperti ijazah, prestise, kontrol atas kelas sosial tertentu, dan kualifikasi sosial lainnya.

- Seseorang yang sekolah membuka kesempatan untuk mengembangkan dirinya dan memudahkan perpindahan memasuki suatu status elit. Seseorang yang sebelumnya berada dalam status sosial yang rendah, bisa naik secara 
langsung atau tidak langsung ke status sosial yang lebih tinggi hanya dengan memasuki sekolah.

- Berdasarkan data empiris yang penulis kemukakan dalam makalah ini, merupakan salah satu bukti bahwa seseorang tidak mesti bekerja sesuai dengan fakultas/jurusan yang ditempuhnya sewaktu mereka kuliah.

\section{DAFTAR PUSTAKA}

Durkheim, Emile, Education and Sociology, New York: The Free Press, 1956

Mastuhu, Memberdayakan Sistem Pendidikan Islam, Jakarta: Logos Wacana Ilmu, 1999

Nasution, S., Sosiologi Pendidikan, Jakarta: Bumi Aksara, 1995

Pammer, William J. Jr, \& Jerri Killian (ed.), Handbook of Conflik Management, New York: Marcel Dekker Inc., 2003

Robertson, Ian, Sociology, New York: Worth Publishers. Inc, Third Edition, 1988

Robinson, Philip, Beberapa Perspektif Sosiologi Pendidikan, Jakarta: Rajawali, 1986

Widiastono, Tonny D., (ed.), Pendidikan Manusia Indonesia, Jakarta: Penerbit Buku Kompas, 2004 